\title{
QuoVadis Regulation of Islamic Economics in Post-Reform Indonesia
}

\author{
Apik Anitasari Intan Saputri \\ IAIN Purwokerto, Indonesia \\ Email: intansaputri@gmail.com
}

\begin{abstract}
This paper describes the regulation of Islamic economics and the urgency of its development, the post-reform Islamic economic, regulatory system, and analyzes the orientation of Indonesian Islamic economic regulation from a political economy perspective. This article's method is a descriptive analysis by analyzing political phenomena that occur in the formulation of Islamic economic regulations in post-reform Indonesia. This qualitative research uses literature studies. The development of Islamic financial regulation in Indonesia is relatively late when referring to Islamic finance development in other countries. This is related to the national political conditions, which are generally less responsive to institutions labeled Islamic. The dramatic changes in Indonesian politics since the fall of the Soeharto regime have made room for real democracy. Islamic banking regulation responds to the Islamic banking industry's development, which requires assurance of legal certainty and legal justice in a clear regulation. The increase in the role of the government in dealing with Islamic economic problems has a big role. According to Islam, economic policies must be supported by social responsibility, limited economic freedom by sharia, multi-ownership recognition, namely private ownership, state ownership, and a high work ethic. The interpretation and development of Islamic economic regulations can be richer and more important if it is based on concrete experiences of development in implementing Islamic economic regulations in Indonesia. In seeking economic laws in line with the rububiyah principle, practical experiences are material for validating Islamic economic laws.
\end{abstract}

Keywords: Regulation, Islamic Economics, Post-Reformation, Indonesia.

\section{A. INTRODUCTION}

Regulations regulate all structures of community life so that they are orderly and orderly. To guarantee compliance with legal or regulatory rules, some requirements are manifested in a set of norms that must be obeyed. Legal regulation in the economic sector implies that various regulations affect economic performance to create human welfare, both in the short and long term. In this case, the regulatory position is to try to reflect the creation of economic justice (Ibrahim \& Handayani, 2009).

Departing from Islamic countries suffering from extraordinary economic backwardness, namely redundant or underuse of human and physical resources. As a result, poverty, underdevelopment, and stagnation occur everywhere. Even though the country is rich in resources, its economy remains underdeveloped. There are structural economic imbalances, wealth and income distribution, a sharp imbalance between several geographic areas, between the economic and social sectors, several economic sectors, particularly agriculture and industry, and inequality in industrial and agricultural centers (Chapra, 1997). 
The impact of the world economic crisis that impacted Indonesia, which started with the rupiah depression in July 1997, and developed into a complex and complex crisis that has caused various social problems such as high unemployment rates, increased poverty rates, low productivity and quality of labor and the destruction of small and medium enterprises on which the people rely (Syarofi, 2016).

This condition even affected the political constellation that occurred in Indonesia, marked by the collapse of the New Order regime, which ruled Indonesia for more than 30 years. During the New Order era, the government limited and tightened supervision of the Islamic political movement activities because it was feared that it would match the government's power. Since the fall of the New Order government regime, there have been enormous changes in the Indonesian nation, including jurisdiction.

When the New Order government ended in 1997, the national economy was in a state of crisis. According to Bahaudin Darus, the cause of the collapse of the national economy was private debt coupled with government debt, which suffered losses after covering six Bank take-over (BTO) that were included in the National Bank Restructuring Agency (IBRA) (Darus, 1998). In the reform era, the community commits to reform in the political, economic, and legal fields, so that post-reform Indonesian Islamic economic regulations are more productive by the government. The paradigm shift in Indonesia after this reform and the deterioration of the economic condition that has not yet recovered requires a top priority scale to become the foundation and guide for economic actors to carry out their activities. That is why the Indonesian government must focus on economic recovery and lay the foundation for sustainable, more efficient, and equitable economic growth (Sulistiyono \& Rustamadji, 2009).

Revolutionary legal development, namely changing consciously and fundamentally the economic, legal system which has been of a liberal quality and under the control of developed countries into an economic, legal system with kinship (ukhuwah) quality or populist quality, as stated in the values of Pancasila and Article 33 UUD 1945. An economical, legal system with family or community quality is also a legal system that does not just rely on the rule of law but pays more attention to the rule of moral or justice rule. This underlies the growth of economic regulation by an economic, legal system, and the norms that live in Indonesian society, namely customary law and Islamic law.

In the reform era, the law became one of the most important issues until the amendment of the 1945 Constitution, which then had a major influence on Indonesian political, economic, and legal policies. Policy in a country is closely related to how people can get happiness, material, and immaterial. At the economic level, the main country is a country with a level of economic growth where all the people enjoy the perfect leadership of a country, both regarding its prosperity and intelligence and spirituality. Chapra added that in addition to material adequacy as a means of fulfilling human primary needs, welfare in the concept of Islamic economy 
must also be realized by a government, including eliminating poverty and creating full employment opportunities for its people, providing social security for the people and striving for equitable economic distribution among the people. Its people (Triyanta et al., 2012).

Indonesia's breakthroughs in its potential in Islamic economics and for the rise of an Islamic economy in Indonesia are closely related to Islamic economic policies and regulations as the basis for economic development policies. Legal policy-making can be done through two things: adapting existing legal provisions and filling the legal void by making new rules in Islamic economics. The state's authority to intervene in economic activities is a fundamental principle, the management of how regulation can work properly in adapting Islamic law that already exists in Islamic legal propositions and designing dynamic regulations and governance.

Regulation and Governance are very dominant in the development of the Islamic economy in Indonesia. Regulations governing how to run an Islamic economic system are a critical topic to discuss. Law products in the political period greatly influenced the birth of regulations due to the development of global and national Islamic economic regulations. Islamic economic regulation will grow together and play a role and act to develop the world Islamic market.

At the beginning of its development, Islamic economic regulation was hampered. This is closely related to national political conditions, which are generally less responsive to institutions or regulations labeled Islamic. The concept of secular nationalism instilled by the colonizers so that they did not see the relationship between religion and the state fosters society. Religion is understood as an individual affair, while religion should not interfere in social, political, and economic matters.

Dawam Raharjo sees the political shift between the New Order government and reformation as a milestone in enacting Islamic regulations in Indonesia, also due to gaps in economic rights. The rationalization of labor policies and the government's deregulation policies were the start of the formation of Indonesian economic regulations in developing and improving social welfare (populist).

Starting from social institutions and Islamic intellectuals' views in Indonesia, who stated that bank interest was dubious and required a conception of the economic system, especially banking institutions by Islamic principles. So that began to urge and force the government to make a regulation in the Islamic banking institution's operation. The Islamic economy movement seems to have continued to increase until now, with the development of all sides of the economy based on the Islamic system in almost all government institutions and society. Islamic economic regulation is needed over time; the Sharia Supervisory Board of the Indonesian Ulama Council also plays a role in answering and issuing Islamic economic fatwas needed by the community.

Reform has become the starting point for the development of Islamic economic regulation in Indonesia. This is the subject of discussion in this paper 
regarding regulating the Islamic economy in post-reform Indonesia from a political economy perspective. This paper describes the regulation of Islamic economics and the urgency of its development, the post-reform Islamic economic, regulatory system, and analyzes the orientation of Indonesian Islamic economic regulation from a political economy perspective.

This article's method is a descriptive analysis by analyzing the political phenomena in the formulation of Islamic economic regulations in post-reform Indonesia. This qualitative research uses a literature study, the data taken as the main literature in books on economics, law, and political economy as the main reference material and economic journals.

\section{B. POLITICS OF ISLAMIC ECONOMIC LAW}

The moral values of Islamic economic development become an illustration of the concept of development of an Islamic society, which is based on the formulation of ethical foundations extracted from the spirit of the Al-Quran and As-Sunnah. These values of morality frame Islamic law as the foundation of the Islamic economic system.

The material of Islamic law can become content in the legislative process through a positivization mechanism. The positivization of Islamic law in the development of national law has 2 (two) forms, namely: first, Islamic law cannot be enforced in the national scope due to the plurality of the Indonesian nation, but Islamic law can be a source of value in the preparation of national law. Second, Islamic law can become positive law that applies to all citizens through a legal, legislative process such as the field of muamalah or Islamic economic law (Umam, 2011).

The positivization of Islamic law has bright prospects because the democratic reform era has a responsive legal character. The Western / Colonial legal system is no longer developed, the majority of the population is Muslim, government politics that support the development of Islamic law, and Islamic law are one of the sources of raw material in the formation of national law in addition to customary law and Western/colonial law.

Islamic law has a universal face in its meaning as Islamic law, derived from the Koran and the hadith of the Prophet Muhammad. As a provision that comes from the Koran and hadith, Islamic law transcends time and space boundaries. Islamic law will appear the same and the same face in any part of the world and at any time.

Muslim countries form cooperation in determining the implementation of Islamic economic regulations through Islamic economic implementation standards. The formation of a group of Muslim-majority developing countries (The Developing-Eight), which includes Indonesia, Iran, Malaysia, Bangladesh, Nigeria, Pakistan, Egypt, and Turkey as the initiator of grouping cooperation the world Islamic economy. Macro, these countries do not have a development strategy that is truly based on Islamic principles. Even in political ideology, it still departs from the 
philosophy of Capitalism and Socialism. Saudi Arabia, Kuwait, Turkey, and the United Arab Emirates still adhere to a capitalistic economic philosophy. Iraq and Libya are closer to socialism. Meanwhile, the one who tried a mixed economy system was Indonesia with the Pancasila Economy format. And the ones that have been very clear and firm in conducting the Islamic economic experiment are Iran and Malaysia. These two countries are seriously implementing alternative economic systems extracted from Islamic treasures (Chapra, 1997).

According to Frank E Vogel \& Samuel L. Hayes, who discussed Islamic law and finance, the initial thought of Islamic finance was not an invention of this century, which was marked by an Islamic political movement initiated by extremist political movements, but rather rooted in from the commands of the Qur'an and the Hadith of the Prophet Muhammad (Vogel \& Hayes, 1998).

Allah guides through His Apostles. These instructions cover everything that humans need, both in faith, morals, and sharia. The two components of faith and morals are constant, while sharia changes according to the needs and level of civilization of the people (Antonio, 2015). This is expressed in the Qur'an. "... For each of the people among you, We provide rules and a clear path ..." (Surah AlMa'idah: 48). Also, by the Prophet, in a hadith, "The Apostles are like brothers and sisters, their mothers (their sharia) are different while they are one (tauhid)." (Bukhari, Abu Dawud, and Ahmad) (Qodri, 2014).

Islamic economics in practice always takes the small people's side; those who are weak and marginalized. In the historical record of Islamic governance, Islamic economic policy is applied in the financial sector and the real sector. Islamic economic life must be realized in a peaceful life without violence because violent conflict will erode partisanship to create equitable justice and prosperity (Asy'ari, 2017).

However, over the course of the centuries, ancient financial practices adopted in Islamic countries adopted a colonial-imposed system with rules established by Western powers. With such a strong influence from Europe, most Islamic countries adopt a banking system and business practices dominated by the Western system. It can be said that the beginning of the implementation of the Islamic financial system in the modern period has occurred along with the independence of Islamic countries after the Second World War (Vogel \& Hayes, 1998).

Based on existing records, the development of Islamic financial regulations in Indonesia is relatively late when referring to Islamic finance developments in other countries. This is related to the national political conditions, which are generally less responsive to institutions labeled Islamic. Although, since the 1940s, one by one,e Muslim countries began to become independent from colonialism, forming an Islamic state through the implementation of Islamic Sharia has experienced many obstacles.

The secular nationalism instilled by the colonizers as a means of struggle has now backfired. The leaders who emerged after colonialism were educated with a secular understanding, so they did not see the relationship between religion and the 
state in fostering society. Religion is understood as an individual affair, while those dealing with socio-political religion should not interfere (Asy'ari, 2017).

The first Islamic financial institution was the Mit Ghamr project, founded in Egypt in 1963, which was immediately followed by the Nasser Social Bank in 1971. The establishment of the Islamic Development Bank (1973) was initiated by the Organization of the Islamic Conference (OIC), whose shares are partially held by the government and some by the private sector. These are the pillars of the modern banking system development. Driven by the desire to break away from the political economy and culture that is dominated by the West, both capitalist and socialist, and the desire to implement things based on Sharia principles, in various countries, several banks have been established based on Sharia principles.

The idea of an Islamic economic system departs from the Islamic world's concerns about the application of the interest system to conventional banks, which some Muslims consider to be included in the category of usury. Therefore, it was in the 1970s, when for the first time, thoughts about the Islamic economic system emerged in the International Conference on Islamic Economics in Mecca in 1976 (Pardede \& Ahyar, 2005). The conference discussed the conventional economic system's failure, with indicators: widening economic disparities between the rich (they have) and the poor (The not have), the continuous economic crisis, economic instability, environmental damage, and the banking industry. Conventions are increasingly moving away from the real sector and only playing with the risk of "derivatives transactions." These aspects can occur due to the root of economic problems, namely Secularism, Individualism, Materialism, interest-based economy, scarcity (Muhamad, 2017).

After the conference, various scientific studies on the Islamic economic system emerged at various Islamic universities. This conference contains several plenary and parallel sessions containing intensive exposures and discussions related to Islamic finance. Besides that, a special discussion session was held to discuss the development of Islamic economics and finance teaching at the university level, which provides experiences and offers various ideas in improving the effectiveness of teaching in Islamic economics.

In addition to the increasing involvement of Sharia experts, the results of the creative work of several international standard-setting bodies, namely: First, AAOIFI (Accounting \& Auditing Organization for Islamic Financial Institution) which was founded in 1991 and based in Bahrain, which emphasizes standardization of audits and accounting or reports. Finance so that Islamic Financial Institutions (LKS) have auditing and financial reporting standards by international standards, but still by sharia principles.

Second, the establishment of the Islamic Financial Services Board (IFSB) in 2001 headquartered in Kuala Lumpur which functions as an institution that sets international standards in the field of Islamic financial services including banking, capital markets, and Islamic insurance, which paved the way for Islamic Finance as a proposition that can be accepted globally. This institution emphasizes the Islamic 
financial industry's regulatory and supervisory aspects to create a stable and prudent Islamic financial system. As of 2017, the IFSB has published twenty-seven standards, guiding principles, guidelines, and technical notes.

Third, the International Islamic Financial Market (IIFM) operates in 2005 and is based in Bahrain. It is an independent institution that focuses on developing local capital markets, especially in the organization of Islamic countries, and providing impetus through its rankings for ethical finance worldwide. Fourth, Participation IIRA (Islamic International Rating Agency) was founded in 2002 and based in Manama. This international institution was established to develop the global Islamic capital market and money market and develop a secondary market for global Islamic financial instruments. IIRA focuses on standardizing contracts and primary and secondary market products, developing sharia compliance instruments in liquidity management, and so on. Fifth, IILM (International Islamic Liquidity Management), founded in 2010 and based in Bahrain, was established to introduce and facilitate effective sharia liquidity management solutions (National, 2018).

Several countries have adopted different models in ratifying and adopting the above international standards. In Malaysia, The Islamic Banking Act 1983 and The Central Bank of Malaysia Act 2009 established the Syariah Advisory Council (SAC) within the Bank Negara structure. In Bahrain, the Islamic finance industry has adopted the standard formulated by AAOIFI. Meanwhile, in England, one of the non-Muslim countries aggressively promotes Islamic finance for domestic and international markets. The country has adopted elements of sharia through the Financial Conduct Authority (FCA). From these international standards, this is the basis for the formation of regulations for the Islamic economy at the world level, affecting Islamic economic regulations in every country, including Indonesia.

The nations of Southeast Asia experienced an economic boom and underwent rapid development at the end of the 20th century. Fast growth in the 1980s and 1990s, averaging 8\% from 1991 to 1997. In Malaysia, in the economic field, Prime Minister Tun Abdul Razak issued the new economic policy controversy after the ethnic riots on 13 May 1969. From economic policy, New Malaysia maintains a lenient ethnic political balance and develops a unique set of rules combining economic growth and political rule favoring Muslim and Muslim Malaysians. Meanwhile, in Brunei Darussalam, customs in Brunei were made into laws acculturated with Islamic teachings. This law had become a guideline for people's lives before the British arrival in Brunei (Asy'ari, 2017). In Indonesia, the intensification of establishing an Islamic bank, developing socio-political and economic conditions and sluggish economic conditions due to the world economic recession, led the Indonesian Ulema Council to sponsor the establishment of an Islamic bank and triggered the formation of various Islamic economic regulations. The government carries out various economic policies and regulations issued in the context of Islamic banking work's independence and effectiveness. 


\section{THE DYNAMICS OF THE POLITICAL CONSTELLATION IN 1998 AND THE OPPORTUNITIES FOR ISLAMIC ECONOMIC REGULATIONS IN INDONESIA}

At the start of the New Order, the emergence of the Islamic economy was still sensitive because it will be opposed to Pancasila's economic concept, in line with the tendency to oppose the concept of "Islamic State" with the State based on Pancasila (Rahardjo, 1997).

Besides, the dramatic changes in Indonesian politics since the Soeharto regime have made room for real democracy. Local politics is becoming more open and determines development in the regions. Before the reformation, the power of the New Order regime has hampered the strengthening of Indonesian politics (Leo Agustino, 2010).

B. J. Habibie's Government Period When he became president, replacing Soeharto in 1998, three important laws were born during the reign of BJ Habibie. The three laws are the Regional Autonomy Law (UU), the Press Law, and the Bank Indonesia Independence Law. The Bank Indonesia Act is the supporting law for the birth of the banking law and the origin of the sharia banking system in the development of sharia economic regulations.

When Abdurrahman Wahid (Gus Dur) was elected President in October 1999, who replaced Habibie, the new program involved a medium-term agenda consisting of four aspects: a medium-term macroeconomic framework, restructuring policies, restructuring economic institutions, and improving resource management. Natural. The macroeconomic framework describes the recovery program while maintaining stability in the price level. However, this program's implementation is quite slow, even after several cabinet reshuffles (Aswicahyono \& Christian, 2017).

The 2001-2004 period held by the Megawati Government was quite successful in building macroeconomic stability, among others due to institutional development, the independence of Bank Indonesia in taking 5 monetary policies, and the restructuring of the Ministry of Finance (under Law Number 17 concerning State Finance) to implement discipline fiscal. However, the Megawati government was less successful in carrying out the 'micro' reforms outlined in the White Paper, especially in improving the investment climate, marked by foreign direct investment, which was negative during the first semester of 2004 (Aswicahyono \& Christian, 2017).

During President Yudhoyono's administration, three major political and economic changes affected efforts and practices of liberalization or economic reform. This administration period opened opportunities for Bank Indonesia independence in implementing and implementing Islamic economic principles.

During his leadership decade, many Islamic financial regulations were issued, namely, Act Number 3 of 2004 concerning Bank Indonesia. Law number 3/2004 is an amendment to Law number 23/1999 concerning Bank Indonesia, Act Number 24 of 2004 concerning the Deposit Insurance Corporation. The enactment of Law no. 24/2004 concerning the Deposit Insurance Corporation (LPS) since 22 September 
2006 marked the start of a new chapter of the deposit insurance regime, Law Number 19 of 2008 concerning State Sharia Securities, Law Number 21 of 2008 concerning Islamic Banking (Itang, 2014 ).

Sharia economic regulation opportunities to develop during the Jokowi administration period are stretching and continuing to move from stagnation. Jokowi officially launched the 2019-2024 Indonesian Sharia Economic Master Plan (MEKSI) at the Office of the National Development Planning Agency in Jakarta on Tuesday, May 14, 2019. The Head of Bappenas, Bambang Brodjonegoro, also said that the plan was launched to answer the challenges and compile a road map to develop the Sharia economy in Indonesia to encourage an increase in national economic growth (Akbar, 2019).

In the second term of President Jokowi, there was a significant increase in the economy, finance, and sharia business development. The goal of becoming the center of the world's sharia economy and finance by 2024. Indonesia's crowning in the 2019 GIFR and the 2019 GIFA (Global Islamic Finance Awards), as received by BAZNAS, IDX, and BTPN Syariah, shows the progressive stretching of Islamic economics and finance and move forward. The role and impact of sharia economic and financial instruments on the condition of the Indonesian economy, the contribution of sharia economy and finance should be increasingly significant in stimulating economic growth, creating jobs, reducing unemployment, reducing poverty, controlling inflation, strengthening people's purchasing power and strengthening the Indonesian economy as a whole. . All components of society can enjoy the impact of economic development and national Islamic finance (Beik, 2019).

\section{ISLAMIC ECONOMIC REGULATION IN INDONESIA POST REFORM}

With recent developments, especially post-reform, the Islamic economy is gaining momentum to be called developing. The strengthening of the issue of sharia can be referred to as a form of new awareness for the Indonesian Muslim community to understand sharia, where sharia is no longer interpreted as something abstract normative, but something that is real-empirical in life (Fealy, 2008).

This strengthening of Sharia's issue is empirically strengthened by the emergence of various economic activities in the name of sharia, such as sharia banks, sharia capital markets, sharia insurance, and sharia pawning. This phenomenon is a reality that explains that the Indonesian Muslim community uses the issue of sharia as an alternative in various aspects of life, including in the economic field (Salim \& Azra, 2018).

Islamic banking regulation responds to the development of the Islamic banking industry, which requires assurance of legal certainty and legal justice in a clear regulation. In the policy dimension of law enforcement (enactment policy), Islamic banking regulations are believed to provide utility and benefit for Indonesia's people. They are seen as in line with the objectives of the national economy. The existence of Islamic banking regulations in Indonesia currently 
strengthens the theory of the politicization of Islamic law and strengthens the paradigm of prophetic law in the national legal system (Ramadhan, 2016).

Many people felt that Islamic regulations were not taken into account before, but many people are starting to feel that they are the solution to the problems that occur. Previously Islamic regulations were underestimated in social life. Currently, it is starting to emerge as a hero. It is seen to continue to exist in a downturn when investment and the journey of the world economy market are experiencing despair. From the time of the proclamation to the 1990s, the word sharia was considered taboo to be included in the realm of legislation. The stigma of sharia in political and legal discourse is perhaps due to a phobia (concern) that the implementation of sharia will lead to the formation of an Islamic state, or at least "the obligation to implement Islamic Sharia for its adherents," as stated in the Jakarta Charter. However, with developments in the last part of the New Order regime, the government and national legal, political policies began to "tolerate" this word so that the stigmatization of sharia was slowly being erased.

The pioneering implementation of the national level sharia economy (finance) began with the establishment of Bank Muamalat Indonesia, which explicitly provides banking operational services with a profit-sharing system (mudharabah). The Islamic banking system's operation obtains the legal basis of Law Number 10 concerning Amendment to Law Number 7 of 1992 concerning Banking. Then it was strengthened again by Law no. 23 of 1992 concerning Bank Indonesia as amended by Law no. 3 of 2004 concerning Bank Indonesia, which allows the implementation of monetary policy based on sharia principles. These two laws form the legal basis for national banking to implement a dual banking system, namely conventional and Islamic banking, which runs in parallel.

On May 7, 2008, in the Islamic capital market for the first time, Law no. 19 of 2008 concerning State Sharia Securities (SBSN) as the legal basis for developing Islamic financial instruments. With the recognition of SBSN as an alternative instrument for state budget financing, the national legislation system has provided a legal basis for mobilizing public funds broadly based on sharia principles. SBSN (State Sukuk), a securities based on sharia principles, so that various forms of Sukuk contracts are known in sharia economics (ijarah, mudharabah, musyarakah, istishna', etc.) can be applied based on Law no. 19 of 2008.

The development of business activities based on sharia principles carried out by limited liability companies is one reason for the replacement of Law no. 1 of 1995 concerning Limited Liability Companies with Law no. 40 of 2007. Limited companies that carry out business activities based on sharia principles, apart from having a Board of Commissioners, must have a Sharia Supervisory Board (DPS), which is appointed by the General Meeting of Shareholders (GMS) on the recommendation of the Indonesian Ulama Council. DPS is in charge of providing advice and suggestions to the Board of Directors and supervising the Company's activities to comply with sharia principles. DPS as an organ of the company that accompanies or complements the Board of Commissioners is tasked with supervising the company's activities so 
that the company's activities do not conduct business activities that are contrary to sharia economic principles (for example, the prohibition of usury - interest money or returns obtained from the use of money to get money - maysir - elements of speculation, gambling, and an attitude of chance - and gharar - elements of uncertainty, which include delivery, quality, and quantity. A Sharia bank is a limited liability company; for this, it must follow the requirements to have a Sharia Supervisory Board in its institution.

In line with the aforementioned developments in sharia legislation, the legislation in judicial bodies also needs to "adjust." UU no. 7 of 1989 concerning the Religious Courts was amended by Law no. 3 of 2006. One of the juridical considerations for this change is the "expansion of the Religious Courts' authority" because "it is by legal developments and society's needs, especially the Muslim community." This expansion includes the Islamic economy. Thus the scope of the jurisdiction of the Religious Courts includes the fields of marriage, inheritance, wills, grants, endowments, zakat, infaq, shadaqah, and sharia economics (Salim, 2020).

\section{E. ANALYSIS OF ECONOMIC AND POLITICAL LAW PERSPECTIVE}

The increase in the role of the government in dealing with Islamic economic problems has a big role. It is time for a Sharia Economy that sided with the weak and weakened defense and empowerment to get greater attention, not only in the financial sector but also in the real sector where there are very sharp gaps. So that the rich are getting richer and the poor are getting poorer and impoverished. Sharia economics, which should reduce gaps in people's lives by applying the principles of economic justice and equity.

According to Islam, economic policy must be supported by social responsibility, limited economic freedom by sharia, recognition of multi ownership, namely private ownership and state ownership, and a high work ethic (Praja, 2010). In the context of social responsibility, or we can call it social security, it is the people's economic rights. It is the state's responsibility in the economic field not to neglect its people in meeting the target of adequacy for their lives (Triyanta, 2012).

Democracy and economic development influence each other. Economic factors and vice versa must accompany political factors. In the field of economic development, the approach is political economy. According to Bung Karno and Bung Hatta, the factor of economic democracy must be considered in the political field. According to the Islamic perspective, economic development must be free from Riba, namely an exploitative, predatory, discriminatory, and corruptive economic system (Rahardjo, 2011).

Sharia banking is regulated by other policies issued by banking authority institutions, namely Bank Indonesia (BI) and the Financial Services Authority (OJK). Since 1999, Bank Indonesia has been given the authority to carry out its duties based on sharia principles. Based on the mandate of Law No. 21 of 2011 concerning the Financial Services Authority, as of December 31, 2012, the functions, duties, and authority of regulating and supervising banking institutions, both conventional and 
Islamic banking, have shifted from Bank Indonesia to OJK. Likewise, activities in the Islamic capital market sector, sharia insurance, sharia pension funds, sharia financing institutions, and other Islamic financial institutions have shifted from the Minister of Finance and the Capital Market Supervisory Agency and Financial Institutions (BAPEPAM-LK) to the OJK. The OJK has issued various policies and regulations in developing Islamic banking and financial institutions in Indonesia.

In the application of regulations and institutional developments that have been facilitated by the government to increase sharia economic growth, in fact, the achievement of the share of the Indonesian Islamic banking market for the last 20 years is still $5 \%$, despite various efforts made by stakeholders through policies to increase the share market according to the targeted. Several things can be raised regarding problems in Islamic banking in Indonesia. The market potential, which is quite large, is not accompanied by a large growth in market share, considering that most of Indonesia's population is Muslim. The condition of Islamic banking human resources, both in terms of quantity and quality and information technology, has not supported the development of Islamic banking products and services (OJK, 2017).

Based on Indonesian banking statistics for the period December 2014 to May 2017, compared to the performance of Islamic banking with conventional banking, in various measures, the banking industry's performance assessment is still below the performance of conventional banking. This shows that the implementation of sharia economic law supremacy in Indonesia is still not optimal. A dual banking system in the banking world, namely conventional banks that apply sharia principles and Islamic banking itself, creates gaps in society in its development.

The growth of Islamic finance has not been able to keep up with conventional financial growth. This can be seen from the share of the Islamic financial market, which, as a whole, is still below $5 \%$. However, when viewed from each type of sharia product, until the end of December 2016, there were several sharia products with a market share of above 5\%, including Islamic banking assets of $5.33 \%$ of all banking assets, state Sukuk which reached 14.82 . \% of total state securities in circulation, Islamic finance institutions of $7.24 \%$ of total financing, specialized Islamic financial services institutions of $9.93 \%$, and Islamic microfinance institutions of $22.26 \%$. The figures above show that Indonesian Islamic finance still needs to be developed to keep up with conventional financial growth to expand the financial industry as a whole (OJK, 2017).

Efforts to improve regulation have not been implemented optimally. The harmony in Islamic banking operations with the changing conditions in the macro and micro economy and political developments affect Indonesia. Research and development aspects are still being developed to find out the latest conditions, both regarding opportunities, challenges, and strengths and weaknesses.

The legislative process of law or any legal provision seen from a socio-legal perspective must create real legal certainty. In connection with the conditions of Indonesian law above, Islamic economic law begins at least when Islamic law has been recognized in the Indonesian legal system (Ridwan, 2016). 
The people's need for sharia financial institutions that provide comfort and are a preference at this time does not seem to have increased so rapidly. Islamic economic regulations have guided the implementation of operations regarding Islamic economic legislation and fatwas, complementing legal protection in Islamic economics implementation.

Islamic financial institutions have problems serving community groups, which are generally informal sector entrepreneurs. Businesses that do not have recording standards and financial reports, apart from being deemed not bankable, their form of business also does not meet the general 5C criteria (character, capacity, capital, condition, and collateral), so formal financial institutions assess MSEs as having a high enough risk (Darsono, 2017).

Education and socialization that are not yet inclusive and reach the wider community must be carried out so that the Islamic finance and banking industry's growth and sustainability can be as targeted. The lack of financial access for the small community in Islamic banking institutions also needs to be criticized. The small community's economy is not facilitated because of their limited knowledge, education, and social strata.

According to Dawan Raharjo, the above conditions are a structural obstacle in the populist economy. These obstacles stem from political policies with the power of capitalism so that there are still gaps in the state's facilities. Banking is a structure facilitated by the government, while access to it is still difficult to pass because the government does not focus on empowering them. HR factors and business capabilities are the government's problems and people (Rahardjo, 2011).

Another institution that has played an important role in forming Islamic banking and financial law in Indonesia is the National Sharia Council of the Indonesian Ulema Council (DSN-MUI). Structurally, the DSN-MUI is an autonomous institution under the MUI. DSN-MUI is given the authority to issue fatwas related to Islamic banking and finance. In principle, the DSN-MUI establishment was intended as an effort of efficiency and coordination of the ulama in responding to issues related to Islamic economic and financial problems. Also, DSN acts as a supervisor, director, and impetus for applying Islamic teachings principles in economic life.

Fatwa issued by the DSN-MUI must be followed by Islamic banking and financial institutions. The DSN-MUI fatwa is positive in Bank Indonesia regulations, Financial Services Authority regulations, and related ministerial regulations. To date, there are 116 fatwas issued by the DSN-MUI. The government has also issued various other regulations to support the development of Islamic banking and financial institutions, including; Law Number 19 of 2008 concerning State Sharia Securities; Law 23 of 2011 concerning Zakat Management; Law No. 41 of 2011 regarding waqf; Law No. 34 of 2014 concerning Hajj Financial Management and Law No. 33 of 2014 concerning the Guarantee of Halal Products.

The development of Islamic banking and financial institutions also affects religious courts' absolute authority in resolving civil disputes. The religious court's 
authority has been expanded since Law NoMOR 7 of 1989 was revised by Law No. 3 of 2006 concerning Religious Courts, which includes the settlement of sharia economic disputes and cases of marriage, inheritance, wills, grants, endowments, and alms. The authority of the Religious Courts to resolve sharia economic disputes is strengthened by Article 55 of Law no. 21 of 2008 concerning Islamic Banking, Constitutional Court Decision No. 93 / PUU-X / 2012, PERMA No. 2 concerning Compilation of Sharia Economic Law, PERMA No. 5 of 2016 concerning Certification of Sharia Judges, and PERMA No. 14 of 2016 concerning the procedures for the settlement of Islamic Economics cases. Based on the data above, that Islamic banking law in Indonesia is growing very rapidly. Islamic Banking and Financial Law emphasize the importance of Islamic Economic Law and the National Law System.

Efforts to positive Islamic civil law are the realization of the dreams of some Muslims since ancient times. During the reign of the Dutch East Indies, the Civil Code (KUHPer) was still applied, which incidentally translated the Dutch colonial creation Borgelijk Wetbook (BW). So that through the coordination of the Supreme Court of the Republic of Indonesia, the Supreme Court Regulation Number 02 of 2008 concerning the Compilation of Islamic Economic Law (KHES) was compiled, which is a response to new developments in the study and practice of muamalat law (sharia economics) in Indonesia (Mughits, 2008). This is in line with the Decision of the Constitutional Court NoMOR 93 / PUU-X / 2012, PERMA No.2 concerning the Compilation of Sharia Economic Law, which further complements the regulatory structure of Sharia Economics in Indonesia.

The political economy analysis is pretty much carried out in the 1945 Constitution. The 1945 Constitution not only contains elements of an economic constitution but also contains constitutional political economy discussions. This analysis is evident in the explanation of Article 23 of the 1945 Constitution, which discusses Bank Indonesia from a democratic perspective. And people's sovereignty. This article clearly discusses the principles of economic democracy and the relationship between economy and politics in the political economy approach.

The discourse of the Indonesian political economy, economic democracy, has its own meaning, as written in the explanation of article 33 of the 1945 Constitution. First, this explanation includes three things regarding economic democracy in the microscope, namely cooperative business entities. Second, the explanation of economic democracy is in the macroscope. This formula contains the concept of Fabian socialism, which argues that socialism is only carried out in production branches that are strategic or important for the country concerned with the people's interests at large. And third, individual ownership. From this constitution's provisions, the dominant sector is cooperatives, then the state sector, and then the private sector (Rahardjo, 2011).

\section{F. CONCLUSION}

Today's Islamic economy is still in the development stage, as is the development of Islamic economic regulations. For Indonesian Muslims, Pancasila 
Economy is an Islamic economy in the Indonesian context. In Kuntowijoyo terms, Pancasila Economics is the objectivity of Islamic Economics. The concept of Islamic economics has so far been better developed so that the concepts and theories of Islamic economics can be used as a basis for the development of the Pancasila economy and of course the determination of Islamic economic regulations in Indonesia.

The interpretation and development of Islamic economic regulations can be richer and more important if it is based on concrete experiences of development in the implementation of Islamic economic regulations in Indonesia. In seeking economic laws in line with the rububiyah principle, practical experiences are material for the validation of Islamic economic laws.

\section{REFERENCES}

1. Antonio, M. S. (2011). Bank Syariah Dari Teori ke Praktek. Jakarta: Gema Insani.

2. Chapra, M. U. (1997). What is Islamic Economics?. Jeddah: IRTI/IDB.

3. Darsono. (2017). Perbankan Syariah di Indonesia: Kelembagaan dan Kebijakan Serta Tantangan ke Depan. Jakarta: Rajawali Pers.

4. Fealy, G. (2008). Consuming Islam: Commodified religion and aspirational pietism in contemporary Indonesia. Expressing Islam: Religious life and politics in Indonesia, 15-39.

5. Hartono, A. (2016). Reformasi Ekonomi Syariah di Indonesia: Analisis Proses Kelahiran Bank Muamalat Indonesia. UNISIA, (29), 13-21.

6. Ibrahim, R., \& Handayani, T. (2009). Penerapan Pernyataan Standar Akuntansi Keuangan Nomor 45 Pada Baitul Mal Provinsi Nanggroe Aceh Darussalam. Jurnal Telaah dan Riset Akuntansi, 2(2), 183-197.

7. Kholis, N. (2011). Potret Politik Ekonomi Islam di Indonesia Era Reformasi. Millah: Jurnal Studi Agama, 10(2), 419-440.

8. Maksum, M. (2016). Kedudukan Syariah sebagai sumber hukum positif: Kajian awal atas hukum perkawinan, ekonomi Islam, dan Hukum ketenagakerjaan di Indonesia dan Maroko. Istinbath: Jurnal Hukum Islam IAIN Mataram, 15(2), 281295.

9. Mannan, M. A. (1986). Islamic Economics: Theory and Practice. Delhi: Idarah-I AdabiyatI.

10. Muttaqien, D. (2008). Reformasi Regulasi dan Kelembagaan Ekonomi Islamdi Indonesia. Jurnal Fakultas Hukum UII, 2(1), 9-22.

11. Pardede, M., \& Ahyar. (2015). Problem Dual Banking System. In Buletin Hukum Perbankan \& Kebanksetralan Vol. 3 - 1 April 2005.

12. Praja, J. S. (2010). Filsafat Hukum Islam. Tasikmalaya: Latifah Press.

13. Qodri, A. (2014). Harta Benda Dalam Perspektif Hukum Islam. Jurnal Penelitian Universitas Jambi: Seri Humaniora, 16(1), 43455.

14. Rahardjo, M. D. (1997). Habibienomics: Telaah Ekonomi Pembangunan Indonesia. Jakarta: Pustaka Cidesindo.

15. Rahardjo, M. D. (2011). Nalar Ekonomi Politik Indonesia. Bogor: IPB Press. 
16. Ramadhan, M. (2016). Politik Hukum Perbankan Syariah di Indonesia. MIQOT: Jurnal Ilmu-Ilmu Keislaman, 40(2).

17. Ridwan, R. (2016). Legislasi Hukum Ekonomi Syariah Dalam Bingkai Hukum Nasional Indonesia. Al-Risalah, 16(1), 95-111.

18. Salim, A., \& Azra, A. (2003). Negara dan Syariat dalam Perspektif Politik Hukum Indonesia. Jakarta: Jaringan Islam Liberal dan The Asia Foundation.

19. Salim, Z. (2020). Legislasi Semu (pseudowetgeving). Direktori Jenderal Peraturan Perundang-Undangan. Retrieved from http://ditjenpp.kemenkumham.go.id/htndan-puu/1299-legislasi-sem u-pseudowetgeving.html.

20. Sulistiyono, A., \& Rustamaji, M. (2009). Hukum Ekonomi Sebagai Panglima. Jakarta: Masmedia Buana Pustaka.

21. Syarofi, A. M. (2016). Kontribusi Hukum Terhadap Perkembangan Perekonomian Nasional Indonesia. Iqtishodia: Jurnal Ekonomi Syariah, 1(2), 57-80.

22. Triyanta, A., Ni'matul Huda, \& Nazriyah, R. (2012). Hukum Ekonomi Islam: Dari Politik Hukum Ekonomi Islam Sampai Pranata Ekonomi Syariah. Depok: FH UII Press.

23. Umam, K. (2011). Manajemen Perbankan Syariah. Bandung: Pustaka Setia.

24. Vogel, F. E., \& Hayes, S. L. (1998). Islamic Law and Finance: Religion, Risk, and Return (Vol. 16). Brill.

25. Yanti, I. (2017). Quo Vadis Peradilan Agama dalam Pengembangan Hukum Ekonomi Syariah di Indonesia. Al-Risalah, 16(02), 255-267.

26. Zulaikha, S. (2013). Pengaruh Globalisasi Ekonomi Terhadap Hukum Ekonomi Islam Di Indonesia. Adzkiya: Jurnal Hukum dan Ekonomi Syariah, 1(1), 1-14. 